\title{
Drug-Induced Parkinsonism
}

\author{
Hae-Won Shin, ${ }^{a}$ Sun Ju Chung ${ }^{b}$ \\ ${ }^{a}$ Department of Neurology, Chung-Ang University College of Medicine, Seoul, Korea \\ ${ }^{b}$ Parkinson/Alzheimer Center, Department of Neurology, University of Ulsan College of Medicine, Seoul, Korea
}

Received April 8, 2011

Revised June 28, 2011

Accepted June 28, 2011

\section{Correspondence}

Sun Ju Chung, MD, $\mathrm{PhD}$

Department of Neurology,

Asan Medical Center,

University of Ulsan

College of Medicine,

88 Olympic-ro 43-gil,

Songpa-gu, Seoul 138-736, Korea

Tel $+82-2-3010-3988$

Fax +82-2-474-4691

E-mail sjchung@amc.seoul.kr
Drug-induced parkinsonism (DIP) is the second-most-common etiology of parkinsonism in the elderly after Parkinson's disease (PD). Many patients with DIP may be misdiagnosed with PD because the clinical features of these two conditions are indistinguishable. Moreover, neurological deficits in patients with DIP may be severe enough to affect daily activities and may persist for long periods of time after the cessation of drug taking. In addition to typical antipsychotics, DIP may be caused by gastrointestinal prokinetics, calcium channel blockers, atypical antipsychotics, and antiepileptic drugs. The clinical manifestations of DIP are classically described as bilateral and symmetric parkinsonism without tremor at rest. However, about half of DIP patients show asymmetrical parkinsonism and tremor at rest, making it difficult to differentiate DIP from PD. The pathophysiology of DIP is related to drug-induced changes in the basal ganglia motor circuit secondary to dopaminergic receptor blockade. Since these effects are limited to postsynaptic dopaminergic receptors, it is expected that presynaptic dopaminergic neurons in the striatum will be intact. Dopamine transporter (DAT) imaging is useful for diagnosing presynaptic parkinsonism. DAT uptake in the striatum is significantly decreased even in the early stage of PD, and this characteristic may help in differentiating PD from DIP. DIP may have a significant and longstanding effect on patients' daily lives, and so physicians should be cautious when prescribing dopaminergic receptor blockers and should monitor patients' neurological signs, especially for parkinsonism and other movement disorders.

J Clin Neurol 2012;8:15-21

Key Words Parkinsonism, dopamine receptor blocking agents, clinical manifestations, dopamine transporter imaging, treatment.

\section{Introduction}

Drug-induced movement disorders include drug-induced parkinsonism (DIP), tardive dyskinesia (TD), tardive dystonia, akathisia, myoclonus, and tremor. Among these, DIP is the most common movement disorder induced by drugs that affect dopamine receptors. ${ }^{1-3}$ Since the clinical manifestations of DIP are very similar to those of Parkinson's disease (PD), patients with DIP are frequently misdiagnosed as having PD. ${ }^{1,4}$ These patients are often prescribed antiparkinsonian drugs unnecessarily for long periods of time, despite recovery being possible simply by discontinuing the offending drugs. Dopamine transporter (DAT) imaging may be used in the differential diagnosis of various etiologies of parkinsonism, including DIP. 5,6 The aim of this review

$($ This is an Open Access article distributed under the terms of the Creative Commons Attribution Non-Commercial License (http://creativecommons.org/licenses/by-nc/3.0) which permits unrestricted non-commercial use, distribution, and reproduction in any medium, provided the original work is properly cited. was to provide clinicians with updated information about the clinical characteristics and DAT imaging findings of patients with DIP, and about the correct treatment for DIP.

\section{Epidemiology of Drug-Induced Parkinsonism}

The exact prevalence and incidence of DIP are unclear because it is frequently unrecognized or misdiagnosed as PD. The first study of the extrapyramidal side effects (EPS) of the antipsychotic chlorpromazine found that about $40 \%$ of these patients exhibited parkinsonism, ${ }^{7}$ and several subsequent epidemiological studies found that DIP is the second most common etiology of parkinsonism. ${ }^{8-10}$ A community-based survey and a population-based study found DIP prevalence rates of $2.7 \%$ and $1.7 \%$, respectively, whereas those of PD were $3.3 \%$ and $4.5 \%$, respectively. ${ }^{8-10}$ However, $6.8 \%$ of the patients diagnosed with PD were later reclassified as having DIP, thus emphasizing the 
difficulties in accurately diagnosing DIP and in measuring its prevalence. ${ }^{4}$ Age is the most obvious risk factor for DIP,,${ }^{11-13}$ since dopamine concentrations decrease and nigral cells degenerate with age. ${ }^{14}$ Another risk factor is female gender, ${ }^{8,15-17}$ suggesting that estrogen suppresses the expression of dopamine receptors; ${ }^{18}$ however, the exact mechanism underlying the gender difference in DIP remains to be clarified. Genetic factors are also thought to be involved in the development of DIP because not all patients taking dopamine receptor blocking agents (DRBAs) develop parkinsonism. ${ }^{19-21}$ Genome-wide screening showed that the genes associated with the gamma-aminobutyric acid (GABA) receptor signaling pathway are involved in neuroleptic-induced TD in schizophrenic patients, ${ }^{21}$ suggesting that genetic factors predispose to both DIP and TD.

\section{Etiology of Drug-Induced Parkinsonism}

Typical antipsychotics, also known as neuroleptics, are the most common causes of DIP. However, atypical antipsychotics, which were thought to be free from EPS, can also induce parkinsonism. In addition to antipsychotics, gastrointestinal (GI) motility drugs, calcium channel blockers (CCBs), and antiepileptic drugs have been found to induce DIP (Table 1).

\section{Antipsychotic drugs}

The history of DIP parallels that of antipsychotics. Parkinsonism as a side effect of chlorpromazine was first reported 3 years after its introduction. ${ }^{7}$ It was soon recognized that all typical antipsychotics had the potential to cause EPS, including parkinsonism, acute dystonia, akathisia, and TD.,22,23 Typical antipsychotics include chlorpromazine, promazine, haloperidol, perphenazine, fluphenazine, and pimozide. About $80 \%$ of patients taking typical antipsychotic drugs exhibit more than one kind of EPS. ${ }^{24}$ Dopamine receptors are widely distributed in the brain, and typical antipsychotics may act on dopamine receptors in the striatum. Therefore, all patients taking antipsy- chotics have some risk of developing parkinsonism and other EPS. Parkinsonism usually appears days to weeks after starting antipsychotics, but in rare cases the onset delay may be several months or more. The risk of EPS was thought to be low for atypical antipsychotics. Atypical antipsychotics include clozapine, risperidone, olanzapine, quetiapine, and aripiprazole. It was originally thought that their relatively low frequency of associated EPS was due to them being more strongly antagonistic toward serotonin-2A receptors than toward dopamine receptors. ${ }^{25-27}$ This serotonin-dopamine hypothesis has long been considered a useful model for developing atypical antipsychotics that exhibit superior antipsychotic efficacy with a lower incidence of EPS compared to typical antipsychotics. ${ }^{25-27}$ The recent 'fastoff' theory suggested that their rapid dissociation from $\mathrm{D}_{2}$ receptors after they have blocked them can explain their lower risk of EPS. ${ }^{28,29}$

In 1989, clozapine became the first atypical antipsychotic drug to be approved by the US Food and Drug Administration. ${ }^{26}$ It is effective in schizophrenia patients with drug-resistant negative symptoms, with an almost complete absence of EPS. DIP due to clozapine has not been reported, and it was found to improve psychosis without aggravating parkinsonism even in PD patients. ${ }^{30}$ However, clozapine has been associated with agranulocytosis in about $1 \%$ of patients, making physicians reluctant to prescribe this drug. Other atypical antipsychotics without the risk of agranulocytosis were developed to control psychosis with minimal EPS. Risperidone was expected to have a minimal risk of EPS because it has a high affinity for serotonin receptors. ${ }^{31}$ However, it binds $\mathrm{D}_{2}$ receptors in a dose-dependent manner, thus inducing parkinsonism and EPS to a similar extent as high doses of typical antipsychotics. ${ }^{31} \mathrm{Al}-$ though the molecular structure of olanzapine is similar to that of clozapine, it carries with it a significant risk of EPS. ${ }^{32}$ Quetiapine is an atypical antipsychotic with a low risk of EPS and a low risk of aggravation of parkinsonism when used to treat psychotic symptoms in patients with $\mathrm{PD}$, and is therefore apparently safe for use in elderly patients..$^{33,34}$ Aripiprazole is the

Table 1. Common offending drugs of drug-induced parkinsonism

\begin{tabular}{|c|c|c|c|}
\hline \multicolumn{2}{|c|}{ Drug frequently causing parkinsonism } & \multicolumn{2}{|c|}{ Drug infrequently causing parkinsonism } \\
\hline Typical antipsychotics & $\begin{array}{l}\text { Phenothiazine: chlorpromazine, prochlorperazine, } \\
\text { perphenazine, fluphenazine, promethazine } \\
\text { Butyrophenones: haloperidol }\end{array}$ & Atypical antipsychotics & Clozapine, quetiapine \\
\hline & Diphenylbutylpiperidine: pimozide & Mood stabilizer & Lithium \\
\hline & Benzamide substitutes: sulpiride & & \\
\hline Atypical antipsychotics & $\begin{array}{l}\text { Risperidone, olanzapine, } \\
\text { ziprasidone, aripiprazole }\end{array}$ & Antidepressant & $\begin{array}{l}\text { SSRI: citalopram, fluoxetine, } \\
\text { praoxetine, sertraline }\end{array}$ \\
\hline Dopamine depleters & Reserpine, tetrabenazine & Antiepileptic drugs & Valproic acid, phenytoin \\
\hline Antiemetics & Metoclopramide, levosulpiride, clebopride & Antiemetics & Domperidone, itopride \\
\hline Calcium-channel blocker & Flunarizine, cinnarizine & & \\
\hline
\end{tabular}

SSRI: selective serotonin reuptake inhibitor. 
most recently introduced novel atypical antipsychotic, and has a unique mechanism of action. Although it was expected to have a low risk of EPS, clinical experiences have been disappointing. ${ }^{35,36}$ Thus, to date, only clozapine and quetiapine are associated with low rates of DIP in older patients.

\section{GI motility drugs}

GI prokinetic drugs, including metoclopramide, levosulpiride, clebopride, itopride, and domperidone, have also been associated with DIP. These drugs have been used clinically to manage motor disorders of the upper GI tract, including functional dyspepsia and emesis. The prokinetic effect of these drugs is mediated through their blockade of enteric inhibitory $\mathrm{D}_{2}$ receptors. ${ }^{37}$ Besides binding to receptors in the peripheral end organs, thus inducing antiemetic effects via $\mathrm{D}_{2}$ receptor blockade in the area postrema, they also antagonize central $\mathrm{D}_{2}$ receptors, leading to adverse effects including hyperprolactinemia and EPS. All prokinetics with $\mathrm{D}_{2}$-receptor-antagonizing properties have been found to induce EPS, although the extent of symptoms varies. Among the GI prokinetics, metoclopramide is the most-well-known cause of drug-induced movement disorders. ${ }^{17,38-40}$ Furthermore, levosulpiride is used widely in several Asian and European countries to treat nausea, vomiting, and functional dyspepsia. Until recently, the drug-induced movement disorders related to levosulpiride were under-recognized, but it has now been shown that levosulpiride frequently causes parkinsonism. ${ }^{41}$ Whereas metoclopramide usually induces TD, levosulpiride causes parkinsonism more frequently than TD or other EPS. Although metoclopramide and levosulpiride have the same mechanism of action, they show different patterns of adverse effects, the reason for which remains to be clarified. In general, domperidone is considered to be safe for the management of GI discomfort, even in patients with PD, because it does not cross the blood-brain barrier. ${ }^{37}$ However, although rare, acute dystonic reactions to this drug may occur. ${ }^{42}$

\section{Other drugs}

Parkinsonism may also be caused by CCBs, antiepileptic drugs, and lithium, although their exact pathophysiological mechanisms are not yet known. CCBs including flunarizine and cinnarizine, which are used to control dizziness and headache, ${ }^{43}$ may cause DIP by reducing dopamine neurotransmission or acting directly on dopamine receptors. ${ }^{44-47}$ The long-term use of valproic acid was found to induce parkinsonism in $5 \%$ of patients, ${ }^{48-50}$ while the exact underlying pathophysiology has not been clarified, one suggestion is that it is due to oxidative stress and mitochondrial dysfunction. ${ }^{50}$ Lithium is an infrequent cause of DIP and is thought to act by decreasing dopamine in the striatum, or as an anticholinesterase that increases central cholinergic activity. ${ }^{51,52}$

\section{Clinical Characteristics of Drug-Induced Parkinsonism}

DIP is generally characterized clinically as bilateral and symmetric parkinsonism, with more prominent bradykinesia and rigidity than in patients with PD. ${ }^{13,53}$ However, it has been suggested in many studies that clinical manifestations alone cannot be used to differentiate DIP from PD (Table 2).

Typically $30-50 \%$ of patients with DIP show asymmetric parkinsonism and tremor at rest; these characteristics are considered to support a PD diagnosis. ${ }^{16,41,44,45,54}$ Interestingly, DIP patients with typical tremor at rest tremors usually also have postural tremors. The similar clinical manifestations of DIP and PD indicate that patients with DIP may have been in a preclinical stage of PD and that their parkinsonism may have been unmasked by the offending drugs. This is supported by findings that parkinsonism persists or even progresses after cessation of the drug in many DIP patients. ${ }^{17,38,40,41,45}$ In a long-term followup study, parkinsonism reappeared several months after the complete resolution from DIP in $7 \%$ of patients; $;{ }^{41}$ DIP might have anteceded PD in those patients.

The mean age at symptom onset is greater for DIP than for PD patients. In addition, DIP is more common in females, whereas males are more likely to have PD. While the duration of symptoms is similar, neurological deficits are more severe in

Table 2. Clinical characteristics of drug-induced parkinsonism

\begin{tabular}{|c|c|c|c|c|c|c|}
\hline & Drug & $\begin{array}{l}\text { Mean } \\
\text { age }\end{array}$ & Gender & $\begin{array}{l}\text { Asymmetric parkinsonism } \\
\text { (percentage } \\
\text { of number of patients) }\end{array}$ & $\begin{array}{l}\text { Tremor (percentage } \\
\text { of number of patients) }\end{array}$ & $\begin{array}{c}\text { Combined TD } \\
\text { (percentage of } \\
\text { number of patients) }\end{array}$ \\
\hline Hardie et al. ${ }^{16}$ & Antipsychotics & 61 & $F>M$ & 44 & Not described & 42 \\
\hline Hassin-Baer et al. ${ }^{54}$ & Antipsychotics & 46 & $\mathrm{~F}<\mathrm{M}$ & 41 & Rest tremor (44\%) & 45 \\
\hline García-Ruiz et al. ${ }^{44}$ & $\begin{array}{l}\text { Calcium channel } \\
\text { blocker }\end{array}$ & 71 & $F>M$ & 36 & $\begin{array}{l}\text { Postural tremor } \\
\text { Rest tremor }\end{array}$ & Not described \\
\hline Martí-Massó et al. ${ }^{45}$ & Cinnarizine & 75 & $F>M$ & 13 & Postural tremor (51\%) & 7 \\
\hline Shin et al. ${ }^{41}$ & Levosulpiride & 70 & $\mathrm{~F}>\mathrm{M}$ & 38 & $\begin{array}{c}\text { Rest tremor (45\%) } \\
\text { Postural tremor (53\%) }\end{array}$ & 7 \\
\hline
\end{tabular}

F: female, M: male, TD: tardive dyskinesia. 
DIP than in PD. Orolingual dyskinesia in drug-naïve PD patients is rare, whereas it is frequently combined with parkinsonism in DIP patients. The symmetry and type of tremor are not useful in distinguishing DIP from PD.

\section{Pathophysiology of Drug-Induced Parkinsonism}

Dopamine receptors in the brain consist of those of the $\mathrm{D}_{1}$ family, comprising $D_{1}$ and $D_{5}$ receptors, and the $D_{2}$ family, comprising $\mathrm{D}_{2}, \mathrm{D}_{3}$, and $\mathrm{D}_{4}$ receptors..$^{55}$ The central dopaminergic system consists of the mesolimbic, mesocortical, tuberoinfundibular, and nigrostriatal pathways. All antipsychotic drugs have potent $D_{2}$ receptor blocking capacity and the therapeutic effects of these drugs on psychosis are related to their action on the limbic system, where they reduce dopamine transmission. The blockage of $\mathrm{D}_{2}$ receptors by antipsychotic drugs in the striatum leads to disinhibition of GABA- and encephalin-containing striatal neurons at the origin of the indirect pathway without alteration of the direct pathway, followed by disinhibition of the subthalamic nucleus. This leads to increased GABAergic inhibition of the thalamocortical projection by facilitation of the inhibitory projection from the globus pallidus/substantia nigra pars reticulata (Fig. 1A). This pathway resembles the model of disturbance of the basal ganglia-motor loop in PD. More than $80 \%$ of $\mathrm{D}_{2}$ receptors were found to be occupied in patients with EPS who were taking neuroleptics ${ }^{56}$ in agreement with results showing that clinical symptoms of PD began when over $80 \%$ of nigral neurons had degenerated.

$\mathrm{TD}$, defined as hyperkinetic movement in the orolingual or oromandibular area, is caused by long-term use of dopaminer- gic blocking agents, and frequently accompanies DIP. The cooccurrence of TD with parkinsonism may be due to dopaminergic receptor supersensitivity resulting from long-term $\mathrm{D}_{2}$ receptor blocking. Chronic administration of these drugs increases dopamine $\mathrm{D}_{2}$ receptor density in the striatum. Moreover, withdrawal from neuroleptics was found to aggravate dyskinetic symptoms, whereas increased doses of neuroleptics transiently suppressed dyskinesia. $\mathrm{D}_{1}$ receptors may also be involved in the development of orolingual dyskinesia when $\mathrm{D}_{2}$ receptors are chronically blocked. Chronic administration of $\mathrm{D}_{2}$ receptor blockers also induces changes in the direct pathway of the basal ganglia-motor loop to activate the striatonigral pathway and increase the inhibition of the striatopallidal pathway (Fig. 1B)..$^{25,57}$ This imbalance between $\operatorname{direct}\left(\mathrm{D}_{1}\right)$ and indirect $\left(\mathrm{D}_{2}\right)$ motor pathways and the resulting alterations in the globus pallidus/substantia nigra pars reticulata complex may lead to hyperkinetic orolingual movements, thus explaining the coexistent and sequential development of parkinsonism and dyskinesia.

\section{Diagnosis of DIP and the Role of DAT Imaging}

The clinical diagnostic criteria for DIP are defined as 1) the presence of parkinsonism, 2) no history of parkinsonism before the use of the offending drug, and 3) onset of parkinsonian symptoms during use of the offending drug. Since asymmetrical rest tremors are common in many DIP patients and symptoms persist or progress after cessation of the offending drug, patients clinically diagnosed with DIP may include individuals in the preclinical stage of PD whose symptoms were unmasked

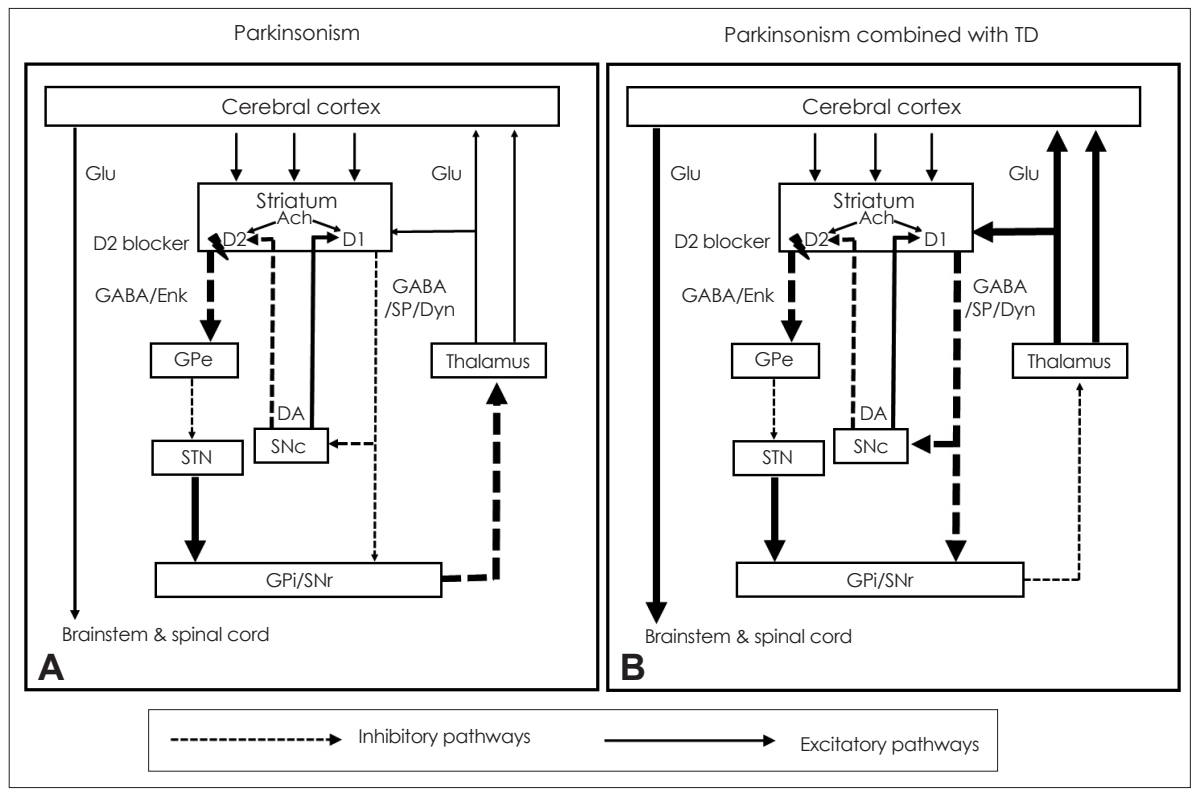

Fig. 1. Changes in basal ganglia-thalamocortical motor loop due to blockade of $D_{2}$ receptors by DRBAs. The blockage of $D_{2}$ receptors by DRBAs in the striatum leads to disinhibition of GABAand encephalin-containing striatal neurons at the origin of the indirect pathway, followed by a disinhibition of the subthalamic nucleus. This leads to increased GABAergic inhibition of the thalamocortical projection by facilitation of the inhibitory projection from the $\mathrm{GPi} / \mathrm{SNr}(\mathrm{A})$. Chronic $\mathrm{D}_{2}$ receptor blockade also induces changes in the direct pathways of the basal ganglia-motor loop to cause orolingual dyskinesia (B). DA: dopamine, DRBAs: dopamine receptor blocking agents, GABA: gammaaminobutyrik acid, GPe: globus pallidus pars externa, GPi: globus pallidus pars internal, SNc: substantia nigra pars compacta, SNr: substantia nigra pars reticulata, STN: subthalamic nucleus, TD: tardive dyskinesia. 
by the drug. ${ }^{15,41,58,59}$

DATs are presynaptic proteins in the membrane on terminals of dopaminergic neurons. They take up dopamine from the synaptic cleft projections that extend from the substantia nigra to the striatum. These transporters control dopaminergic transmission by spatial and temporal buffering, rendering the molecule an imaging target in diseases affecting the dopaminergic nigrostriatal pathway. Single-photon-emission computed tomography (SPECT) and positron-emission tomography (PET) scans are available using several DAT ligands. ${ }^{6,60}$ SPECT radioligands include ${ }^{123} \mathrm{I}-\mathrm{N}$-3-fluoropropyl-2 $\beta$-carbomethoxy-3 $\beta$-(4iodophenyl)nortropane ( ${ }^{123} \mathrm{I}-\mathrm{FP}-\mathrm{CIT}$ or ${ }^{123} \mathrm{I}-\beta$-CIT-FP), ${ }^{123} \mathrm{I}$ ioflupane, DaTSCAN, and ${ }^{123} \mathrm{I}-2 \beta$-carbomethoxy-3 $\beta$-(4iodophenyl)tropane ( ${ }^{123}$ I- $\beta$-CIT $) .{ }^{61}$ PET scans may be superior to SPECT for imaging DATs, in that the lower energy of positrons provides higher resolution, resulting in better image quality with widespread clinical applications ${ }^{60}$ However, most DAT imaging studies, including those in patients with DIP, have utilized SPECT. ${ }^{53,62-64}$

DAT uptake in the striatum is significantly decreased in PD patients, even during the early stages of the disease, because the motor symptoms of PD do not appear until $60-80 \%$ of dopaminergic neurons degenerate. ${ }^{65}$ In addition, drugs causing parkinsonism, such as DRBAs, have negligible affinity for DAT. ${ }^{66,67}$ DAT scans may show symmetric uptake of radiotracer in the bilateral striatum in patients with pure DIP, even if they have significant parkinsonism (Fig. 2A). PD can be diagnosed in DIP patients whose DAT uptake decreases asymmetrically in the striatum (Fig. 2B). Therefore, DAT scans may be useful for differentiating PD unmasked by drugs from pure DIP. Follow-up DAT scans of DIP patients with initially normal DAT scans exhibited normal uptake in the striatum, whereas scans of patients with initially decreased DAT scans in the striatum exhibited progressive reduction of striatal tracer up-

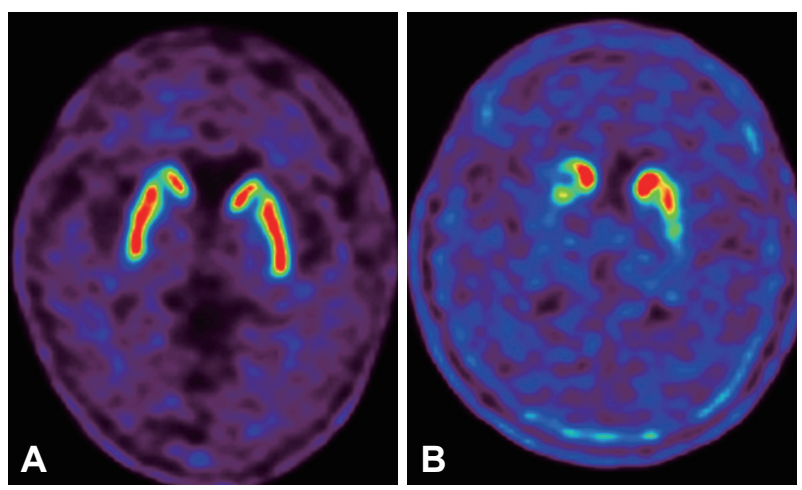

Fig. 2. ${ }^{123}$-FP-CIT PET imaging in two DIP patients. DAT uptake was normal and symmetric in the bilateral striatum in a pure DIP patient (A), whereas it decreased severely in the right striatum in a patient who was diagnosed with PD unmasked by DRBAs (B). DAT: dopamine transpoter, DIP: drug-induced parkinsonism, DRBA: dopamine receptor blocking agents, PD: Parkinson's disease. take. ${ }^{62}$ These findings suggest that DAT imaging provides useful information for diagnosing DIP and may help in the design of a therapeutic plan. Further studies involving larger numbers of patients are needed to determine the sensitivity and specificity of DAT scans in DIP diagnosis.

\section{Treatments and Outcomes of DIP}

DIP is generally treated by cessation of the offending drugs. Patients who cannot stop taking antipsychotic drugs because of their psychiatric diseases, such as those with schizophrenia or major depressive disorders, may be switched to atypical antipsychotics that have a lower risk of EPS. People who are prescribed dopamine antagonists due to simple GI disturbance, headache, dizziness, or insomnia should stop taking the offending drugs as soon as possible. Anticholinergics including trihexyphenidyl, benztropine, amantadine, and levodopa have been empirically tested for their ability to relieve symptoms of DIP, but this has produced no clear evidence of their effects in DIP patients. ${ }^{3,16,54,68,69}$

DIP usually resolves within weeks to months after stopping the offending drug; however, parkinsonism may persist or progress in $10-50 \%$ of patients. The prognosis of patients with DIP can be classified into the following types: 1) full and longlasting recovery from DIP with no subsequent development of parkinsonism, 2) persistence but not progression of parkinsonism, 3) persistence and eventual worsening of parkinsonism, and 4) full remission of parkinsonism but later reappearance after discontinuation of the offending drug. Only patients classified as type 1 can be defined as having 'pure DIP', whereas those classified as type 3 or 4 may be in the preclinical stages of PD. ${ }^{67}$ The finding of Lewy bodies in two DIP patients who had completely recovered after stopping the offending drugs $^{70}$ suggests that clinical course alone cannot distinguish 'pure DIP' among patients clinically diagnosed with DIP. In DIP patients classified as type 2 , the persistence of parkinsonism may be due to permanent DRBA-induced damage to dopamine receptors. ${ }^{71,72}$ DAT imaging may be useful in diagnosing DIP patients and predicting their clinical course. A large prospective study may provide more information on the exact prognosis and factors related to recovery in DIP patients.

\section{Conclusions}

DIP is important because it is a common etiology of parkinsonism and is frequently either unrecognized or misdiagnosed as PD. In addition, parkinsonism in DIP patients is sufficiently severe to affect daily activities and may persist for long periods of time even after cessation of the offending drug. DAT imaging may be useful for accurately diagnosing patients with DIP 
and may help to identify the clinical characteristics and exact prognosis of this disorder.

About $50 \%$ of patients with DIP and other movement disorders are treated with DRBAs for conditions unrelated to psychosis, including depression, GI disturbance, anxiety, and insomnia. ${ }^{1}$ Physicians should avoid prescribing DRBAs and CCBs for inappropriate reasons such as anxiety, insomnia, dizziness or dyspepsia in elderly patients and should monitor these patients' neurological signs, especially parkinsonism and other movement disorders, when prescribing these drugs.

\section{Conflicts of Interest}

The authors have no financial conflicts of interest.

\section{REFERENCES}

1. Miller LG, Jankovic J. Neurologic approach to drug-induced movement disorders: a study of 125 patients. South Med J 1990;83:525-532.

2. Montastruc JL, Llau ME, Rascol O, Senard JM. Drug-induced parkinsonism: a review. Fundam Clin Pharmacol 1994;8:293-306.

3. Sethi KD. Movement disorders induced by dopamine blocking agents. Semin Neurol 2001;21:59-68.

4. Esper CD, Factor SA. Failure of recognition of drug-induced parkinsonism in the elderly. Mov Disord 2008;23:401-404.

5. Kägi G, Bhatia KP, Tolosa E. The role of DAT-SPECT in movement disorders. J Neurol Neurosurg Psychiatry 2010;81:5-12.

6. Scherfler C, Schwarz J, Antonini A, Grosset D, Valldeoriola F, Marek $\mathrm{K}$, et al. Role of DAT-SPECT in the diagnostic work up of parkinsonism. Mov Disord 2007;22:1229-1238.

7. Hall RA, Jackson RB, Swain JM. Neurotoxic reactions resulting from chlorpromazine administration. J Am Med Assoc 1956;161:214-218.

8. Benito-León J, Bermejo-Pareja F, Rodríguez J, Molina JA, Gabriel R, Morales JM; Neurological Disorders in Central Spain (NEDICES) Study Group. Prevalence of PD and other types of parkinsonism in three elderly populations of central Spain. Mov Disord 2003;18:267-274.

9. Wenning GK, Kiechl S, Seppi K, Müller J, Högl B, Saletu M, et al. Prevalence of movement disorders in men and women aged 50-89 years (Bruneck Study cohort): a population-based study. Lancet Neurol 2005;4:815-820.

10. Barbosa MT, Caramelli P, Maia DP, Cunningham MC, Guerra HL, Lima-Costa MF, et al. Parkinsonism and Parkinson's disease in the elderly: a community-based survey in Brazil (the Bambuí study). Mov Disord 2006;21:800-808.

11. Avorn J, Bohn RL, Mogun H, Gurwitz JH, Monane M, Everitt D, et al. Neuroleptic drug exposure and treatment of parkinsonism in the elderly: a case-control study. Am J Med 1995;99:48-54.

12. Susatia F, Fernandez HH. Drug-induced parkinsonism. Curr Treat Options Neurol 2009;11:162-169.

13. Thanvi B, Treadwell S. Drug induced parkinsonism: a common cause of parkinsonism in older people. Postgrad Med J 2009;85:322-326.

14. Volkow ND, Ding YS, Fowler JS, Wang GJ, Logan J, Gatley SJ, et al. Dopamine transporters decrease with age. J Nucl Med 1996;37:554559.

15. Stephen PJ, Williamson J. Drug-induced parkinsonism in the elderly. Lancet 1984;2:1082-1083.

16. Hardie RJ, Lees AJ. Neuroleptic-induced Parkinson's syndrome: clinical features and results of treatment with levodopa. J Neurol Neurosurg Psychiatry 1988;51:850-854.

17. Miller LG, Jankovic J. Metoclopramide-induced movement disorders. Clinical findings with a review of the literature. Arch Intern Med 1989; 149:2486-2492

18. Bedard P, Langelier P, Villeneuve A. Oestrogens and extrapyramidal system. Lancet 1977;2:1367-1368.

19. Metzer WS, Newton JE, Steele RW, Claybrook M, Paige SR, McMillan DE, et al. HLA antigens in drug-induced parkinsonism. Mov Disord 1989;4:121-128.

20. Liou YJ, Wang YC, Chen JY, Bai YM, Lin CC, Liao DL, et al. Association analysis of polymorphisms in the N-methyl-D-aspartate (NMDA) receptor subunit 2B (GRIN2B) gene and tardive dyskinesia in schizophrenia. Psychiatry Res 2007;153:271-275.

21. Inada T, Koga M, Ishiguro H, Horiuchi Y, Syu A, Yoshio T, et al. Pathway-based association analysis of genome-wide screening data suggest that genes associated with the gamma-aminobutyric acid receptor signaling pathway are involved in neuroleptic-induced, treatment-resistant tardive dyskinesia. Pharmacogenet Genomics 2008;18:317-323.

22. Shanon J, Kaplan SM, Pierce CM, Ross WD. An interesting reaction to a tranquilizer: tonic seizures with perphenazine (trilafon). Am J Psychiatry $1957 ; 114: 556$

23. Christian CD, Paulson G. Severe motility disturbance after small doses of prochlorperazine. N Engl J Med 1958;259:828-830.

24. Janno S, Holi M, Tuisku K, Wahlbeck K. Prevalence of neuroleptic-induced movement disorders in chronic schizophrenia inpatients. Am J Psychiatry 2004;161:160-163.

25. Ossowska K. Neuronal basis of neuroleptic-induced extrapyramidal side effects. Pol J Pharmacol 2002;54:299-312.

26. Tarsy D, Baldessarini RJ, Tarazi FI. Effects of newer antipsychotics on extrapyramidal function. CNS Drugs 2002;16:23-45.

27. Kuroki T, Nagao N, Nakahara T. Neuropharmacology of second-generation antipsychotic drugs: a validity of the serotonin-dopamine hypothesis. Prog Brain Res 2008;172:199-212.

28. Kapur S, Seeman P. Does fast dissociation from the dopamine d(2) receptor explain the action of atypical antipsychotics?: a new hypothesis. Am J Psychiatry 2001;158:360-369.

29. Stahl SM. "Hit-and-Run" actions at dopamine receptors, part 2: illustrating fast dissociation from dopamine receptors that typifies atypical antipsychotics. J Clin Psychiatry 2001;62:747-748.

30. Low-dose clozapine for the treatment of drug-induced psychosis in Parkinson's disease. The Parkinson Study Group. N Engl J Med 1999; 340:757-763.

31. Schotte A, Janssen PF, Gommeren W, Luyten WH, Van Gompel P, Lesage AS, et al. Risperidone compared with new and reference antipsychotic drugs: in vitro and in vivo receptor binding. Psychopharmacology (Berl) 1996;124:57-73.

32. Gómez JC, Sacristán JA, Hernández J, Breier A, Ruiz Carrasco P, Antón Saiz C, et al. The safety of olanzapine compared with other antipsychotic drugs: results of an observational prospective study in patients with schizophrenia (EFESO Study). Pharmacoepidemiologic Study of Olanzapine in Schizophrenia. J Clin Psychiatry 2000;61:335-343

33. Rabey JM, Prokhorov T, Miniovitz A, Dobronevsky E, Klein C. Effect of quetiapine in psychotic Parkinson's disease patients: a doubleblind labeled study of 3 months' duration. Mov Disord 2007;22:313318.

34. Juncos JL, Roberts VJ, Evatt ML, Jewart RD, Wood CD, Potter LS, et al. Quetiapine improves psychotic symptoms and cognition in Parkinson's disease. Mov Disord 2004;19:29-35.

35. Wickremaratchi M, Morris HR, Ali IM. Aripiprazole associated with severe exacerbation of Parkinson's disease. Mov Disord 2006;21:15381539 .

36. Sharma A, Sorrell JH. Aripiprazole-induced parkinsonism. Int Clin Psychopharmacol 2006;21:127-129.

37. Tonini M, Cipollina L, Poluzzi E, Crema F, Corazza GR, De Ponti F. Review article: clinical implications of enteric and central D2 receptor blockade by antidopaminergic gastrointestinal prokinetics. Aliment Pharmacol Ther 2004;19:379-390.

38. Kenney C, Hunter C, Davidson A, Jankovic J. Metoclopramide, an increasingly recognized cause of tardive dyskinesia. J Clin Pharmacol 2008;48:379-384. 
39. Parkinsonism: an under-recognised complication of metoclopramide use. Ceylon Med J 1996;41:125.

40. Sethi KD, Patel B, Meador KJ. Metoclopramide-induced parkinsonism. South Med J 1989;82:1581-1582.

41. Shin HW, Kim MJ, Kim JS, Lee MC, Chung SJ. Levosulpiride-induced movement disorders. Mov Disord 2009;24:2249-2253.

42. Madej TH. Domperidone--an acute dystonic reaction. Anaesthesia 1985;40:202.

43. Sørensen PS, Hansen K, Olesen J. A placebo-controlled, double-blind, cross-over trial of flunarizine in common migraine. Cephalalgia 1986;6: 7-14.

44. Garc1'a-Ruiz PJ, Javier Jiménez-Jiménez F, Garc1'a de Yébenes J. Calcium channel blocker-induced parkinsonism: clinical features and comparisons with Parkinson's disease. Parkinsonism Relat Disord 1998;4: 211-214.

45. Martí-Massó JF, Poza JJ. Cinnarizine-induced parkinsonism: ten years later. Mov Disord 1998;13:453-456.

46. Negrotti A, Calzetti S. A long-term follow-up study of cinnarizine- and flunarizine-induced parkinsonism. Mov Disord 1997;12:107-110.

47. Takada M, Kono T, Kitai ST. Flunarizine induces a transient loss of tyrosine hydroxylase immunoreactivity in nigrostriatal neurons. Brain Res 1992;590:311-315.

48. Onofrj M, Thomas A, Paci C. Reversible parkinsonism induced by prolonged treatment with valproate. J Neurol 1998;245:794-796.

49. Easterford K, Clough P, Kellett M, Fallon K, Duncan S. Reversible parkinsonism with normal beta-CIT-SPECT in patients exposed to sodium valproate. Neurology 2004;62:1435-1437.

50. Jamora D, Lim SH, Pan A, Tan L, Tan EK. Valproate-induced Parkinsonism in epilepsy patients. Mov Disord 2007;22:130-133.

51. Reches A, Tietler J, Lavy S. Parkinsonism due to lithium carbonate poisoning. Arch Neurol 1981;38:471.

52. Holroyd S, Smith D. Disabling parkinsonism due to lithium: a case report. J Geriatr Psychiatry Neurol 1995;8:118-119.

53. Tinazzi M, Antonini A, Bovi T, Pasquin I, Steinmayr M, Moretto G, et al. Clinical and [123I]FP-CIT SPET imaging follow-up in patients with drug-induced parkinsonism. J Neurol 2009;256:910-915.

54. Hassin-Baer S, Sirota P, Korczyn AD, Treves TA, Epstein B, Shabtai H, et al. Clinical characteristics of neuroleptic-induced parkinsonism. $J$ Neural Transm 2001;108:1299-1308.

55. Jaber M, Robinson SW, Missale C, Caron MG. Dopamine receptors and brain function. Neuropharmacology 1996;35:1503-1519.

56. Farde L, Nordström AL, Wiesel FA, Pauli S, Halldin C, Sedvall G. Positron emission tomographic analysis of central D1 and D2 dopamine receptor occupancy in patients treated with classical neuroleptics and clozapine. Relation to extrapyramidal side effects. Arch Gen Psychiatry 1992;49:538-544.

57. Gunne LM, Andrén PE. An animal model for coexisting tardive dyski- nesia and tardive parkinsonism: a glutamate hypothesis for tardive dyskinesia. Clin Neuropharmacol 1993;16:90-95

58. Gershanik OS. Drug-induced parkinsonism in the aged. Recognition and prevention. Drugs Aging 1994;5:127-132.

59. Jiménez-Jiménez FJ, Ortí-Pareja M, Ayuso-Peralta L, Gasalla T, Cabrera-Valdivia F, Vaquero A, et al. Drug-induced parkinsonism in a movement disorders unit: a four-year survey. Parkinsonism Relat Disord 1996; 2:145-149.

60. Davis MR, Votaw JR, Bremner JD, Byas-Smith MG, Faber TL, Voll $\mathrm{RJ}$, et al. Initial human PET imaging studies with the dopamine transporter ligand 18F-FECNT. J Nucl Med 2003;44:855-861.

61. Varrone A, Halldin C. Molecular imaging of the dopamine transporter. J Nucl Med 2010;51:1331-1334.

62. Diaz-Corrales FJ, Sanz-Viedma S, Garcia-Solis D, Escobar-Delgado T, Mir P. Clinical features and 123I-FP-CIT SPECT imaging in drug-induced parkinsonism and Parkinson's disease. Eur J Nucl Med Mol Imaging 2010;37:556-564.

63. Lorberboym M, Treves TA, Melamed E, Lampl Y, Hellmann M, Djaldetti R. [123I]-FP/CIT SPECT imaging for distinguishing drug-induced parkinsonism from Parkinson's disease. Mov Disord 2006;21:510-514.

64. Tinazzi M, Ottaviani S, Isaias IU, Pasquin I, Steinmayr M, Vampini C, et al. [123I]FP-CIT SPET imaging in drug-induced Parkinsonism. Mov Disord 2008;23:1825-1829.

65. Poewe W, Scherfler C. Role of dopamine transporter imaging in investigation of parkinsonian syndromes in routine clinical practice. Mov Disord 2003;18 Suppl 7:S16-S21.

66. Lavalaye J, Linszen DH, Booij J, Dingemans PM, Reneman L, Habraken $\mathrm{JB}$, et al. Dopamine transporter density in young patients with schizophrenia assessed with [123]FP-CIT SPECT. Schizophr Res 2001; 47:59-67.

67. Tolosa E, Coelho M, Gallardo M. DAT imaging in drug-induced and psychogenic parkinsonism. Mov Disord 2003;18 Suppl 7:S28-S33.

68. Fann WE, Lake CR. Amantadine versus trihexyphenidyl in the treatment of neuroleptic-induced parkinsonism. Am J Psychiatry 1976;133: 940-943.

69. Jankovic J. Tardive syndromes and other drug-induced movement disorders. Clin Neuropharmacol 1995;18:197-214.

70. Rajput AH, Rozdilsky B, Hornykiewicz O, Shannak K, Lee T, Seeman P. Reversible drug-induced parkinsonism. Clinicopathologic study of two cases. Arch Neurol 1982;39:644-646.

71. Bishnoi M, Chopra K, Kulkarni SK. Protective effect of adenosine reuptake inhibitors in haloperidol-induced orofacial dyskinesia and associated behavioural, biochemical and neurochemical changes. Pharmacology 2007;79:171-183.

72. Tsai G, Goff DC, Chang RW, Flood J, Baer L, Coyle JT. Markers of glutamatergic neurotransmission and oxidative stress associated with tardive dyskinesia. Am J Psychiatry 1998;155:1207-1213. 